\title{
Bioactive Compounds Profile of Alkaloid on Elaeocarpus sphaericus Schum Seeds by Liquid Chromatography-Mass Spectrometry
}

\author{
Cicilia Novi Primiani1 ${ }^{*}$, Pujiati ${ }^{1}$, Mohammad Arfi Setiawan ${ }^{2}$ \\ ${ }^{1}$ Department of Biology Education, Universitas PGRI Madiun, East Java Indonesia \\ ${ }^{2}$ Department of Chemical Engineering, Universitas PGRI Madiun, East Java Indonesia \\ ${ }^{*}$ Corresponding author. Email: primiani@unipma.ac.id
}

\begin{abstract}
Elaeocarpus sphaericus Schum with the local name genitri has medicinal plant properties. Therefore, this study aims to identify the diversity of alkaloid compounds in genitri seeds using the Liquid Chromatography-Mass Spectrometry (LC-MS) method. The Extract Purification through Solid Phase Extraction (SPE) was conducted using C18 Sep-Pak. Based on the LCMS results, several alkaloids were obtained in the genital seeds with different compositions namely, Elaeokanine C $0.90 \%$, (+)-elaeocarpine $1.59 \%$, Elaeocarpenine 1.88\%, Isoelaeocarpine 1.36\%, Grandisine B $0.86 \%$, Isoelaeocarpiline 1.14\%, Grandisine D 1.51\%, Elaeocarpidine 1.03\%, Isoelaeocarpicine 1.89\%, Grandisine F $1.39 \%$, Grandisine A $0.89 \%$, Grandisine C $0.98 \%$, Grandisine E $1.14 \%$, Habbemine A $1.24 \%$, Habbemine B $1.46 \%$, Grandisine G $0.85 \%$. Furthermore, the bioavailability of these compounds was determined through Phytochemical Analysis.
\end{abstract}

Keywords: alkaloids, compounds profile, Elaeocarpus sphaericus, LCMS

\section{INTRODUCTION}

Biodiversity of plants can thrive in Indonesia due to geographical conditions, especially with a tropical climate, and they have medicinal properties. Previous studies showed that plants have various active compounds used as medicine. Elaeocarpus sphaericus Schum medicinal plant is one of the 360 species of the Elaeocarpaceae family that can grow in tropical and sub-tropical areas. This species is a local endemic plant that has not been fully utilized, and it is used as shade, firewood, seeds are used for jewelry. Several studies showed that genitri can be used as a medicinal plant [1$3]$ due to the complex compounds [4-5]. Furthermore, the chemical compounds have pharmacological activities that can be used in the treatment of diseases [3],[6]. The ethanolic extract of E. ganitrus seed of 250 $\mathrm{mg} / \mathrm{kg}$ and $500 \mathrm{mg} / \mathrm{kg}$ (p.o) affected the normal kidney tissue structure of rabbits fed with cholesterol [7]. Meanwhile, E. tectorius seed extract $40.06 \mathrm{mg}$ has antioxidant and antimicrobial properties [8]. $E$. tonkinesis leaf extract has anti-influenza ability [5]. One of the chemical compounds in plants are alkaloids, and they contain heterocyclic nitrogen atoms [9-10] that are synthesized in various plants. Alkaloids in pure compounds have the characteristics of colorless, nonvolatile, crystalline, tend to taste bitter [11], and they have various physiological effects on the human body [12-13]. Qualitative and quantitative methods are conducted to identify the phytochemical properties of natural materials [14]. Liquid Chromatograph Mass Spectrometry (LC-MS) is one of these analytical methods that combines the separation capabilities of liquid chromatography (LC) against a target compound. Furthermore, this compound is obtained from the mixture of mass spectroscopic capabilities (mass spectrometry/MS) which can read the spectrum of the separated target compound [15]. This study aims to analyze the compounds of the alkaloid group of Elaeocarpus sphaericus Schum seeds using the LC-MS method.

\section{METHOD}

\subsection{Materials}

Dried genetri seeds were obtained from a forest area in Magetan, East Java, Indonesia. 


\subsection{Sample Preparation}

The seeds were washed and dried using a microwave at $60{ }^{\circ} \mathrm{C}$, then mashed using a blender, and 100-250 g were taken after being smooth. Furthermore, the seed powder was dissolved in $95 \%$ methanol in a ratio of 1:5 (sample: methanol), and the solution was stirred until homogeneous. It was left to stand for 24 hours at a cold temperature in a closed bottle, and the filtration process was further conducted to obtain the filtrate and dregs using an Erlenmeyer vacuum filter. The process was repeated three times by dissolving with methanol until the dregs were obtained. The combined filtrate was evaporated from the methanol to obtain a semi-viscous extract using half of the previous solution.

\subsection{Extract Dilution}

A vortex was used to dissolve the extract with methanol to a concentration below $100 \mathrm{ppm}$ until a homogeneous solution was obtained. Furthermore, the solids were separated by centrifuging at a speed of 8000 $\mathrm{rpm}$ for 10 minutes, and the obtained supernatant was used in the next stage.

\subsection{Protein Precipitation}

In the centrifuge tube, $2 \mathrm{ml}$ of supernatant extract was added to $3 \mathrm{ml}$ of acetonitrile acidified with $0.2 \%$ formic acid. The centrifugation was conducted at a speed of $8000 \mathrm{rpm}$ for 30 seconds to obtain another supernatant.

\subsection{Purification with SPE (Solid Phase Extraction)}

The supernatant was put into a Sep-Pak C18 Cartridge $(1 \mathrm{ml}, 100 \mathrm{mg})$ which had been conditioned with $1 \mathrm{ml}$ 80:20 (acetonitrile: water), and about $0.5 \mathrm{ml}$ of the solution was accommodated with $1 \mathrm{ml}$ of the sample into the Sep - Pak column. Furthermore, $0.5 \mathrm{ml}$ of 80:20 acetonitrile/water solution was added into the Sep - Pak column, and $0.5 \mathrm{ml}$ of the solution that comes out was accommodated. Then, $0.25 \mathrm{ml}$ of $200 \mathrm{mM}$ ammonium formate was added in a 50:50 solution of acetonitrile/methanol to the Sep-Pak column. The obtained $0.5 \mathrm{ml}$ was added with $0.2 \mathrm{ml}$ of $25: 75$ acetonitrile: buffer ( $25 \mathrm{mM}$ ammonium formate $\mathrm{pH} 4.5$ ), and the solution was used for injection in LCMS. Furthermore, the filtration was conducted using a membrane filter of $0.45 \mathrm{~m}$ cellulose acetate, and Table 1 showed the LCMS specifications.

Table 1. Specifications of LC-MS

\begin{tabular}{|l|l|}
\hline $\begin{array}{l}\text { LC-MS apparatus } \\
\text { model }\end{array}$ & $\begin{array}{l}\text { Shimadzu LC-MS - 8040 } \\
\text { LC/MS }\end{array}$ \\
\hline Column & $\begin{array}{l}\text { Shimadzu Shim Pack FC-ODS } \\
(2 \mathrm{~mm} \times 150 \mathrm{~mm}, 3 \mu \mathrm{m})\end{array}$ \\
\hline Injection volume & $1 \mu \mathrm{l}$ \\
\hline Capillary voltage & $3,0 \mathrm{kV}$ \\
\hline $\begin{array}{l}\text { Column } \\
\text { temperature }\end{array}$ & $35^{\circ} \mathrm{C}$ \\
\hline $\begin{array}{l}\text { Mobile phase } \\
\text { mode }\end{array}$ & Isocratic \\
\hline Flow rate & $0,5 \mathrm{ml} / \mathrm{min}$ \\
\hline Sampling cone & $23,0 \mathrm{~V}$ \\
\hline Solvent & Ethanol 95\% \\
\hline $\begin{array}{l}\text { MS focused ion } \\
\text { mode }\end{array}$ & 10 type [M]+ \\
\hline Collison energy & $5,0 \mathrm{~V}$ \\
\hline $\begin{array}{l}\text { Desolvation gas } \\
\text { flow }\end{array}$ & $60 \mathrm{ml} / \mathrm{hr}$ \\
\hline $\begin{array}{l}\text { Desolvation } \\
\text { temperature }\end{array}$ & $350^{\circ} \mathrm{C}$ \\
\hline $\begin{array}{l}\text { Fragmentation } \\
\text { method }\end{array}$ & $\mathrm{Low}$ energy CID \\
\hline lonization & $\mathrm{ESI}$ \\
\hline Scanning & $0,6 \mathrm{sec} / \mathrm{scan}(\mathrm{mz}: 10-1000)$ \\
\hline $\begin{array}{l}\text { Source } \\
\text { temperature }\end{array}$ & $100^{\circ} \mathrm{C}$ \\
\hline Run time & $80 \mathrm{minutes}$ \\
\hline LCMS method & $\mathrm{LCMS} \mathrm{method}$ \\
\hline
\end{tabular}

\section{RESULTS}

Table 2 showed the analysis of genitri seed alkaloids using the LC-MS method, with specifications. In addition, it showed the composition of each compound based on the analysis of the alkaloid group using the LC-MS method of genitri seeds.

Table 2. Results of LC-MS analysis of compounds from the seed alkaloid group Elaeocarpus sphaericus Schum

\begin{tabular}{|c|c|c|c|c|c|c|}
\hline $\begin{array}{c}\text { Peak } \\
\text { number }\end{array}$ & $\begin{array}{c}\text { RT } \\
(\mathrm{min})\end{array}$ & $\begin{array}{c}\text { Similarity } \\
\text { index (\%) }\end{array}$ & Curve area & $\begin{array}{c}\text { Composition } \\
(\%)\end{array}$ & \multicolumn{2}{|c|}{ Compound Result } \\
\cline { 5 - 7 } 15 & 6,409 & 92 & 605,71886 & 0,90496 & Analysis & \\
\hline 16 & 8,034 & 92 & 1068,8228 & 1,59685 & elaeokanine C \\
\hline
\end{tabular}




\begin{tabular}{|c|c|c|c|c|c|c|}
\hline Peak & RT & Similarity & Curve area & Composition & & Result \\
\hline & & & & & Analysis & Structure \\
\hline 17 & 8,041 & 92 & 1261,48853 & 1,88470 & elaeocarpenine & \\
\hline 18 & 8,045 & 92 & 911,78578 & 1,36223 & isoelaeocarpine & \\
\hline 19 & 8,165 & 92 & 578,55872 & 0,86438 & grandisine B & \\
\hline 20 & 8,304 & 92 & 760,64328 & 1,13642 & isoelaeocarpiline & \\
\hline 21 & 8,322 & 92 & 1009,42285 & 1,50810 & grandisine D & \\
\hline 22 & 8,74 & 92 & 690,42761 & 1,03152 & elaeocarpidine & \\
\hline 23 & 9,732 & 92 & $\begin{array}{c}1515,8679 \\
7\end{array}$ & 2,26475 & naringenin & \\
\hline 24 & 9,805 & 92 & 1261,78616 & 1,88514 & isoelaeocarpicine & \\
\hline 25 & 9,847 & 92 & 927,65515 & 1,38594 & grandisine F & \\
\hline
\end{tabular}




\begin{tabular}{|c|c|c|c|c|c|c|}
\hline \multirow{2}{*}{$\begin{array}{l}\text { Peak } \\
\text { number }\end{array}$} & \multirow{2}{*}{$\begin{array}{c}\mathrm{RT} \\
(\mathrm{min})\end{array}$} & \multirow{2}{*}{$\begin{array}{l}\text { Similarity } \\
\text { index }(\%)\end{array}$} & \multirow[t]{2}{*}{ Curve area } & \multirow{2}{*}{$\begin{array}{c}\text { Composition } \\
(\%)\end{array}$} & \multicolumn{2}{|c|}{ Compound Result } \\
\hline & & & & & Analysis & Structure \\
\hline 26 & 9,851 & 92 & 596,84565 & 0,89170 & grandisine A & \\
\hline 27 & 9,855 & 92 & 659,15586 & 0,98480 & grandisine C & \\
\hline 28 & 9,859 & 92 & 760,66456 & 1,13645 & grandisine $\mathrm{E}$ & \\
\hline 29 & 9,97 & 92 & 831,55537 & 1,24237 & habbemine $\mathrm{A}$ & \\
\hline 30 & 9,973 & 92 & 976,88686 & 1,45949 & habbemine $B$ & \\
\hline 34 & 10,52 & 92 & 568,08828 & 0,84874 & grandisine $\mathrm{G}$ & \\
\hline
\end{tabular}

Isoelaeocarpicine, Grandisine $\mathrm{F}$, Grandisine $\mathrm{A}$,

\section{DISCUSSION}

The analysis results of the alkaloid group using the LC-MS method of genitri seeds showed different compounds, namely Elaeokanine C, (+)-elaeocarpine, Elaeocarpenine, Isoelaeocarpine, Grandisine $\mathrm{B}$, Isoelaeocarpiline, Grandisine D, Elaeocarpidine,
Grandisine C, Grandisine E, Habbemine A, Habbemine B, Grandisine G. Alkaloids are one of the active compounds in genitri seeds, and the results of the LCMS analysis showed that the highest content was Isoelaeocarpicine compound, which is about $1.89 \%$. Figure 1 showed the structural analysis of Isoelaeocarpicine, with a chemical formula of $\mathrm{C}_{16} \mathrm{H}_{21} \mathrm{NO}_{3}$ and a molecular weight of 275.3480 . 

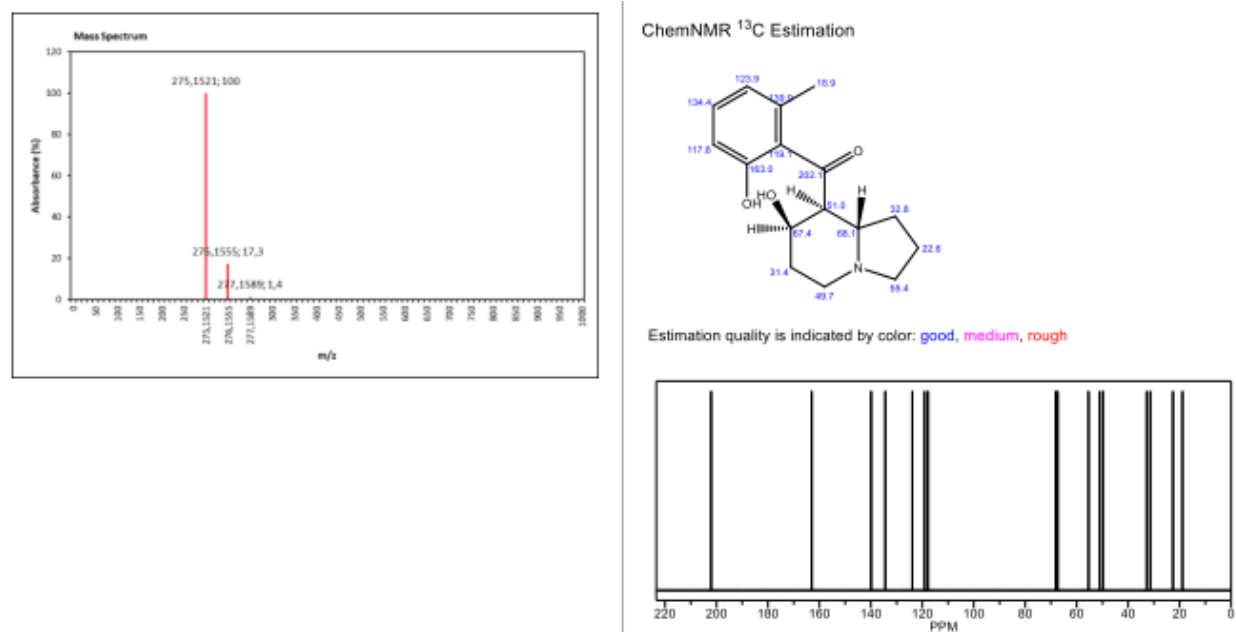

Figure 1. Isoelaeocarpicine, one of the alkaloid compounds in genitri seeds, indicated by the adsorption value and chemical structure

Liquid Chromatography-Mass Spectrometry (LCMS) is an analytical technique that combines the physical separation capabilities of liquid chromatography with the detection specificity of mass spectrometry [16]. It separates the components of the sample and the charged ions are detected by a mass spectrometer, and the result can be used to provide information about the molecular weight, structure, identity, and quantity of certain sample components [17]. Furthermore, the compounds are separated based on their relative interaction with the chemical layer of the particles (stationary phase) and the elution of the solvent through the column (mobile phase). This method can analyze a wider range of components, such as thermolabile compounds, high polarity or high molecular mass, and proteins. The font in the row header should be bold and you can use the style available from the style palette.

Alkaloids are one of the secondary metabolites in genitri seeds, and they have medicinal plants properties [18-21]. Furthermore, alkaloids in Uncaria rhynchophylla have been identified as an anti-dengue virus [20]. These compounds can inhibit the growth of Staphylococcus aureus and Pseudomonas aeruginosa bacteria in Callistemon citrinus and Vernonia adoensis leaves [19]. Previous studies showed that alkaloid compounds have immunomodulatory properties [22].

\section{CONCLUSION}

A phytochemical analysis is an important factor used to determine the components of chemical compounds in plants. Furthermore, Liquid Chromatography-Mass Spectrometry (LC-MS) was used to analyze the alkaloid compounds of genitri seeds, and different compounds were obtained, namely Elaeokanine C $0.90 \%$, (+)elaeocarpine $1.59 \%$, Elaeocarpenine $1.88 \%$, Isoelaeocarpine $1.36 \%$, Grandisine B $0.86 \%$, Isoelaeocarpiline $1.14 \%$, Grandisine D $1.51 \%$,
Elaeocarpidine $\quad 1.03 \%$, Isoelaeocarpicine $1.89 \%$, Grandisine F $1.39 \%$, Grandisine A $0.89 \%$, Grandisine C $0.98 \%$, Grandisine E $1.14 \%$, Habbemine A $1.24 \%$, Habbemine B $1.46 \%$, Grandisine G $0.85 \%$.

\section{ACKNOWLEDGMENTS}

Thank you as well to Ministry of Research, Technology and Higher Education of Indonesia for supporting in research funding.

\section{REFERENCES}

[1] M. Pant, A. Lal, P. Bisht, A. Rani, Elaeocarpus sphaericus: A tree with curative powers: an overview. Research Journal of Medicinal Plant, vol. 7(1), 2013, pp. 23-31. DOI: https://doi.org/10.3923/rjmp.2013.23.31

[2] S. Jain, K. Jatwa, V. Jain, A. Sharma, S.C. Mahajan, A review on elaeocarpus sphaericus (Rudraksha). PharmaTutor, vol. 2(7), 2014, pp. $83-$ 91.

[3] S. Hardainiyan, B.C Nandy, K. Kumar, Elaeocarpus ganitrus (Rudraksha): A reservoir plant with their pharmacological effects. Int $\mathbf{J}$ Pharm Sci Rev Res, vol. 34(1), 2015, pp. 55-64.

[4] D.H. Geetha, M. Rajeswari, I. Jayashree, Chemical profiling of Elaeocarpus serratus L. by GCMS. Asian Pacific journal of tropical biomedicine, vol. 3(12), 2013, pp. 985-987. DOI: https://doi.org/10.1016/S2221-1691(13)60190-2

[5] N.T Dao, Y. Jang, M. Kim, H.H. Nguyen, et.al., Chemical Constituents and Anti-influenza Viral Activity of the Leaves of Vietnamese Plant Elaeocarpus tonkinensis. Records of Natural Products, vol. 13(1), 2019, pp. 71-80. DOI: https://doi.org/10.25135/rnp.76.18.04.266 
[6] S. Jawla, D.V Rai, Pharmacognostic Studies on Rudraksh (Elaeocarpus angustifolius Blume) Fruit. Advances in Biological Research, vol. 10(6),2016, pp. 382-387.

[7] P.K. Jain, P. Sharma, S.C Joshi, Effect of elaeocarpus ganitrus roxb. On kidney function of cholesterol fed rabbits. Advances in Pharmacology and Toxicology, vol. 18(2), 2017, pp. 1-9.

[8] A.L. Manoharan, S. Thamburaj, K. Muniyandi, et.al., Antioxidant and antimicrobial investigations of Elaeocarpus tectorius (Lour.) Poir. fruits against urinary tract infection pathogens. Biocatalysis and Agricultural Biotechnology, vol. 20, 2019, 101260. DOI: https://doi.org/10.1016/j.bcab.2019.101260

[9] N. Bribi, Pharmacological activity of alkaloids: a review. Asian Journal of Botany, vol. 1(1), 2018.

[10] J. Himanshu, Jadon, G., Bhadauria, R. S., \& Kishor, A. A review article on: plant alkaloids, International Journal of Pharmaceutical Erudition, vol. 9(4), 2020, pp. 1-5.

[11] P.B. Saxena, Chemistry of alkaloids. Discovery Publishing House, 2007.

[12] C.P. Kumar, J. Sachin, Pharmacological action of plant alkaloids in female reproductive system of test animals and/or human beings: A review. Int. J. Pharm. Sci. Rev. Res, vol. 23(2), 2013, pp. 98-107.

[13] K.L. Kohnen-Johannsen, O. Kayser, Tropane alkaloids: chemistry, pharmacology, biosynthesis and production. Molecules, vol. 24(4), 2019, pp. 796.

DOI:

https://doi.org/10.3390/molecules24040796

[14] K.P. Ingle, A.G. Deshmukh, D.A. Padole, et.al., Phytochemicals: Extraction methods, identification and detection of bioactive compounds from plant extracts. Journal of Pharmacognosy and Phytochemistry, vol. 6(1), 2017, pp 32-36.

[15] W.M.A. Niessen, Liquid chromatography-mass spectrometry. Crc Press, 2006.

[16] P.R. Kumar, S.R. Dinesh, R. Rini, LCMS-a review and a recent update. J Pharm Pharm Sci, vol. 5(5), 2016, pp. 377-391.

[17] N. Zhang, S.T. Fountain, H. Bi, D.T Rossi, Quantification and rapid metabolite identification in drug discovery using API time-of-flight LC/MS. Analytical chemistry, vol. 72(4), 2000, pp. 800-806. DOI: https://doi.org/10.1021/ac9911701

[18] D.E. Okwu, F.U. Nnamdi, Cannabinoid Dronabinol alkaloid with antimicrobial activity from Cassia alata Linn. Der Chemica Sinica, vol. 2(2), 2011, pp. 247-254.
[19] D. Mabhiza, T. Chitemerere, S. Mukanganyama, Antibacterial Properties of Alkaloid Extracts from Callistemon citrinus and Vernonia adoensis against Staphylococcus aureus and Pseudomonas aeruginosa. International Journal of Medicinal Chemistry, 2016. DOI: https://doi.org/10.1155/2016/6304163

[20] T. Hishiki, F. Kato, S. Tajima, et.al., Hirsutine, an indole alkaloid of uncaria rhynchophylla, inhibits late step in dengue virus lifecycle. Frontiers in microbiology, vol. 8, 2017, 1674. DOI: https://doi.org/10.3389/fmicb.2017.01674

[21] W. Wang, X. Yang, Y. Chen, et.al., Seneciphylline, a main pyrrolizidine alkaloid in Gynura japonica, induces hepatotoxicity in mice and primary hepatocytes via activating mitochondria-mediated apoptosis. Journal of Applied Toxicology, vol. 40(11), 2020, pp. 1534-1544. DOI: https://doi.org/10.1002/jat.4004

[22] D.S. Senchina, J.E. Hallam, M.L. Kohut, et.al., Alkaloids and athlete immune function: caffeine, theophylline, gingerol, ephedrine, and their congeners. Exercise immunology review, vol. 20, 2014, pp. 68-93 